\title{
Pelatihan Analisis Statistik Untuk Karya Tulis Ilmiah Bagi Guru-Guru SMA Kediri
}

\author{
Training of Statistics Analysis in Scientific Papers \\ for Senior High School Teacher in Kediri
}

\section{A’yunin Sofro, Affiati Oktaviarina, Dwi Juniati dan I Ketut Budayasa}

\author{
Universitas Negeri Surabaya, Email: ayuninsofro@unesa.ac.id
}

\begin{abstract}
Abstrak
Menulis suatu karya ilmiah merupakan salah satu upaya untuk meningkatkan profesionalisme guru. Akan tetapi, bagi seorang guru menulis adalah pekerjaan yang tidak mudah. Salah satu kendalanya adalah minimnya kemampuan guru untuk menganalisis data pada karya tulis ilmiah tersebut. Keadaan yang serupa terdapat pada perhimpunan guru dibidang matematika di Kediri. Oleh karena itu, solusi yang ditawarkan dalam kegiatan pengabdian kepada masyarakat (PKM) adalah mengadakan suatu pelatihan terkait analisis data dalam suatu karya tulis ilmiah. Dalam kegiatan pelatihan telah dilakukan sesi pemaparan materi baik secara teori maupun aplikasi pada software. Anggota yang hadir sebanyak 33 orang. Pada akhir kegiatan, telah dibentuk kelompok kecil yang terdiri dari 3 sampai dengan 4 peserta untuk menyelesaikan soal secara komprehensif. Hasil dari pelatihan ini akan dievaluasi baik dari sisi output maupun proses. Untuk kriteria output, yaitu ketuntasan pemahaman seluruh kelompok telah terpenuhi dimana lebih dari 75 persen tuntas. Artinya dari seluruh anggota peserta dalam kelompok, hanya sekira $25 \%$ mendapatkan nilai 75 dari 100 dan sisanya mendapatkan nilai sempurna. Selain itu, ketuntasan pemahaman materi oleh setiap kelompok telah berhasil mencapai target yaitu diatas 75 persen ketuntasan. Hal ini dikarenakan ada 6 kelompok mendapatkan nilai sempurna (100) dan hanya 2 kelompok melakukan kesalahan minor dan hasil evaluasinya adalah 75. Sedangkan segi proses, respon yang diberikan oleh seluruh peserta juga sangat positif. Dengan demikian, dapat disimpulkan bahwa pelatihan telah berhasil sesuai dengan kriteria sisi output dan proses.
\end{abstract}

Kata kunci: analisis statistik, karya tulis ilmiah, guru, profesionalisme

\begin{abstract}
Writing a scientific work is one of the efforts to improve teacher professionalism. However, for a teacher writing is not easy task. One obstacle is the lack of the teacher's ability to analyze data on the scientific paper. A similar situation is found in the teacher association in mathematics in Kediri. Therefore, the solution which is offered in programme of dedication or Pengabdian kepada Masyarakat (PKM) is to conduct a training related to data analysis in a scientific paper. In the training activity, there was a presentation session on material both in theory and application in software in software R studio. Members have attended 33 teachers. At the end of the activity, a small group of 3 to 4 participants was formed to solve the problem comprehensively. The results of this training will be evaluated both in terms of output and process criterion. For output criterion, the comprehension of the entire group has been fulfilled, more than 75 percent people in the workshop are able to complete the tasks. It means that from all participants in the group, only about $25 \%$ get a score of 75 out of 100 and the remain get a perfect score. In addition, the comprehension of material understanding by each group has succeeded in achieving the target of above 75 percent completeness. This is because there are 6 groups that get perfect scores (100) and only 2 groups make minor errors and the results of the evaluation are 75 . While in terms of the process criterion, the responses given by all participants were also very positive. Thus, it can be concluded that the training has succeeded in accordance with the criteria of the output and process side.
\end{abstract}

Key words: statistics analysis, scientific paper, teacher, profesionalism 


\section{PENDAHULUAN}

Guru memegang peranan yang sangat penting dalam mendukung program pemerintah yang selalu berupaya meningkatkan kualitas pendidikan. Sebagai pendidik yang berusaha meningkatkan kualitas pembelajaran yang diberikan tentunya guru harus dapat memberikan pembelajaran yang membantu siswanya untuk mempelajari berbagai hal, untuk melihat apakah pembelajaran yang dilakukan sudah sesuai dengan yang diharapkan tentunya guru diharapkan dapat melakukan evaluasi terhadap pembelajarannya. Oleh karena itu, sebagai seorang guru diharapkan untuk selalu meningkatkan profesionalismenya, [1]. Salah satu hal bisa dilakukan adalah dengan melakukan suatu publikasi penelitian, [2]. Terdapat berbagai macam penelitian yang bisa dilakukan terkait pembelajaran dalam upaya memberikan yang terbaik bagi siswanya yang semuanya dapat dituangkan dalam suatu tulisan ilmiah.

Akan tetap, menulis suatu karya tulis ilmiah merupakan tantangan tersendiri bagi seorang guru. Dalam kenyataannya, sangat langka ditemukan guru yang mau, mampu dan bisa membuat karya tulis ilmiah, [3]. Beberapa kendala yang dihadapi adalah guru kesulitan didalam membaca artikel, guru tidak mempunyai waktu untuk menulis, terdapat gab yang antara peneliti dan guru, [4]. Menurut [5], guru memerlukan pendampingan untuk melakukan penelitian dan publikasi.

Dalam karya tulis ilmiah tersebut, tidak hanya memaparkan tentang pentingnya permasalahan yang diangkat, akan tetapi hal yang berkaitan dengan analisis data juga merupakan hal yang sangat penting, [6]. Dengan menggunakan analisis yang tepat, diharapkan penelitian akan mampu membantu guru dalam menyelesaikan dan mengambil keputusan yang tepat dalam bidang pembelajaran. Untuk mempermudah melakukan analisis statistik tentunya dibutuhkan software statistik, sehingga adanya pelatihan analisis data dengan suatu software akan sangat dibutuhkan.

Salah satu sekolah di Jawa Timur yang berkembang dengan pesat adalah SMA di Kediri. Sekolah menengah di Kediri memiliki peranan yang sangat signifikan didalam membangun perkembangan bidang pendidikan di Jawa Timur. Beberapa sekolah SMA di kediri telah menjadi SMA terbaik di Jawa Timur. Hal ini karena sepenuhnya didukung oleh guru guru yang profesional dan sarana prasarana yang memadai. Hampir separuh lebih SMA di Kediri telah memiliki perpustakaan, laboratorium Fisika dan laboratorium Komputer. Akan tetapi pada kenyataannya mendapatkan seorang guru yang mau dan bisa membuat suatu karya tulis ilmiah. Harapannya, dengan adanya laboratorium komputer tentunya akan mempermudah para guru menghasilkan karya tulis ilmiah secara optimal.

Untuk mendukung proses tersebut maka tim pelaksana kegiatan pengabdian pada masyarakat jurusan Matematika FMIPA Unesa akan mengadakan kegiatan pelatihan analisis statistik pada karya tulis ilmiah bagi guru-guru di SMA di Kediri, dengan tujuan memaparkan peranan karya tulis ilmiah bagi guru, peranan statistika dalam karya tulis ilmiah dan melatih guru-guru sehingga dapat melakukan analisis statistik dengan bantuan software R studio.

\section{SOLUSI/TEKNOLOGI}

Berdasarkan uraian sebelumnya, maka solusi yang ditawarkan adalah melakukan pelatihan analisis statitika pada karya tulis ilmiah dengan menggunakan bantuan software $\mathrm{R}$ studio. Peserta kegiatan Pelatihan analisis statistik adalah guru-guru SMA di Kediri. Tetapi dalam pelaksanaan nanti ditargetkan minimal 25 orang hadir termasuk kepala

Sedangkan kerangka pemecahan masalah yang akan dilakukan adalah meliputi rangkaian berikut ini : 
1. Pemaparan materi tentang peranan karya tulis ilmiah untuk meningkatkan profesionalitas seorang guru

2. Pemaparan tentang konsep dan peranan statistika didalam suatu karya tulis ilmiah

3. Pelatihan analisis statistik dengan menggunakan software.

4. Pada kegiatan ini guru-guru menyelesaikan tugas melakukan analisis statistik dengan menggunakan software yang diajarkan secara berkelompok dan di akhir kegiatan guru mendiskusikan hasil pekerjaannya.

Khalayak sasaran antara yang strategis pada kegiatan ini Kepala sekolah SMA di Kediri, sedang khalayak sasarannya adalah 25 guru SMA di Kediri. Institusi yang terkait dalam kegiatan ini adalah sebagai berikut:

1. Jurusan Matematika menyediakan 4 dosen sebagai nara sumber pada kegiatan pelatihan ananlisis statistik bagi guru-guru SMA di Kediri,

2. SMA di Kediri memfasilitasi dan mengkoordinasi kegiatan ini dengan menyediakan tempat dan mengkoordinasi guru peserta workshopLPPM berperan sebagai lembaga yang memberikan legalitas terhadap kegiatan ini.

3. Fakultas MIPA berperan sebagai lembaga yang memberi ijin pada dosennya untuk melaksanakan kegiatan ini.

4. Unesa berperan dalam memberi ruang dan ijin bagi dosennya untuk melaksanakan kegiatan pengabdian pada masyarakat ini.

Untuk mencapai tujuan kegiatan maka metode yang digunakan adalah :

1. Kegiatan yang pertama adalah pemaparan tentang peranan karya tulis ilmiah bagi profesionalisme guru.

2. Kegiatan yang kedua adalah pemaparan tentang peranan statistika dalam karya tulis ilmiah.
3. Kegiatan yang selanjutnya adalah pendampingan guru-guru dalam melakukan analisis dengan menggunakan software. Dalam kegiatan ini guru dibagi dalam kelompokkelompok untuk melakukan analisis statistika pada suatu karya ilmiah.

Sedangkan untuk penilaian dilakukan dalam dua tahap, yaitu persiapan, dan pelaksanaan pelatihan, yaitu :

1. Pada tahap persiapan, penilaian dilakukan terhadap kesiapan handout untuk peserta, bahan presentasi, serta tersedianya sarana dan prasarana. Jika telah tersedia sesuai dengan yang direncanakan, maka dikatakan persiapan sudah baik atau memenuhi kelayakan. Selanjutnya yaitu tahap pelaksanaan.

2. Pada tahap pelaksanaan hal-hal yang akan dinilai ada dua hal. Yang pertama adalaha kriteria keberhasilan dari sisi output.

Kegiatan ini dikatakan berhasil jika paling sedikit $75 \%$ untuk setiap kelompok dan seluruh kelompok mampu melakukan analisis data dari data yang diberikan dengan menggunakan software dan memberikan kesimpulan yang sesuai. Keberhasilan ini dilihat dari hasil penyelesaian tugas yang dikerjakan oleh guru. Sedangkan yang kedua adalah kriteria keberhasilan dari sisi proses.

Proses kegiatan dikatakan berhasil, jika peserta memberikan respon positif, cenderung antusias, menyatakan kegiatan perlu untuk ditindaklanjuti, kegiatan bermanfaat meningkatkan kemampuan guru dan memotivasi guru untuk menjadi guru yang lebih baik lagi. Untuk mengetahui hal tersebut pada akhir kegiatan diberikan angket yang mengungkap pendapat-pendapat tersebut. 


\section{HASIL DAN DISKUSI}

Kegiatan pengabdian kepada masyarakat (PKM) dilaksanakan pada hari Sabtu tanggal 4 Agustus 2018 dari mulai jam 9.00 sampai dengan 12.30 bertempat di SMAN 1 Kediri. Sebanyak 33 peserta telah hadir dalam pelatihan yang tergabung dalam forum MGMP Matematika baik kota maupun kabupaten.

Pada sesi pertama, pelatihan dibuka oleh salah satu anggota PKM dan langsung diteruskan dengan paparan mengenai pentingnya peningkatan profesionalisme guru melalui penulisan karya tulis ilmiah. Materi kemudian dilanjutkan dengan kajian peningkatan mutu karya tulis ilmiah dengan penggunaan analisis statistika yang tepat. Sesi selanjutnya adalah tentang pemaparan analisis statistika untuk karya tulis ilmiah dengan beberapa sub topik yaitu uji Z, uji T dan chi square. Selama proses pemaparan materi tersebut, kegiatan ini telah didukung oleh dua mahasiswa dari jurusan matematika. Mereka bertugas menginstall program $\mathrm{R}$ studio yang akan didemonstrasikan selama proses pelatihan.

Pada saat akhir penyajian uji hipotesis, pemateri membagi peserta menjadi 8 kelompok kecil yang terdiri dari 3 sampai 4 anggota. Kemudian penyaji mendemostrasikan analisis beberapa uji diatas dengan menggunakan software $\mathrm{R}$ dan langsung diikuti oleh setiap peserta dalam kelompok. Sedangkan pada sesi evaluasi, pada pelatihan ini kita beri waktu sekitar satu setengah jam untuk mengerjakan secara komprehensif satu kasus dalam pembelajaran dari tiga pilihan yang tersedia dalam bentuk kelompok.

Hasil evaluasi dari pelaksanaan pelatihan adalah bahwa kegiatan ini telah mencapai kriteria keberhasilan yang ditetapkan. Hal yang pertama adalah ketuntasan keberhasilan dari penyelesaian problem secara komprehensif dengan menggunakan software $\mathrm{R}$ studio telah diatas $75 \%$. Beberapa fakta yang mendasari hal tersebut adalah dari seluruh anggota peserta dalam kelompok, hanya sekira $25 \%$ mendapatkan nilai 75 dari 100 dan sisanya mendapatkan nilai sempurna. Faktor yang kedua adalah ketuntasan pemahaman materi oleh setiap kelompok telah berhasil mencapai target yaitu diatas 75 persen ketuntasan. Hal ini dikarenakan ada 6 kelompok mendapatkan nilai sempurna (100) dan hanya 2 kelompok melakukan kesalahan minor sehingga hasil evaluasinya adalah 75. Selain itu, sebanyak 4 atau 5 kelompok telah berhasil menyelesaikan semua soal yang disediakan. Tentu hal ini semakin memperkuat fakta bahwa pelatihan ini berhasil mencapai keberhasilan seperti yang diharapkan.

Kriteria yang kedua adalah adanya respon yang positif selama pelatihan. Selama pelatihan, respon yang didapatkan sangatlah positif antara lain pelatihan sangat baik, cukup menarik dalam menjelaskan materi, cara penyampaian bagus, penyaji sangat sabar dan baik. Sedangkan saran saran yang diperoleh dari angket adalah sangat perlu dilanjutkan karena belum menguasai materi statistika, untuk data yang lebih dari 40 dan pengolahan evaluasi soal dengan software.

Sedangkan untuk angket no 1 (pendapat Bapak/ibu berkaitan dengan materi pelatihan), peserta menjawab A (materi dan penyajian menarik ) sebanyak 90,91\%. Angket no 2 (Apakah materi yang diberikan dapat membantu Bapak/Ibu untuk melaksanakan tugas?.) dan sebanyak 96,97 $\%$ peserta menjawab A (ya, sangat membantu). Untuk angket no 3 (Apakah pengetahuan analisis statistik merupakan kebutuhan multak untuk mendukung pemuatan karya tulis ilmiah Bapak/ibu), sebanyak $81,82 \%$ peserta menjawab A (sangat membutuhkan).

Untuk angket no 4, menyatakan hampir $100 \%$ peserta menyatakan tidak tersedia program statistika yang sesuai dengan kebutuhan. Dengan adanya pelatihan ini, harapannya adalah peserta mampu menganalisis dan menggunakan software $\mathrm{R}$ studio sebagai salah satu alternatif solusi persoalan diatas. Tingginya antusias peserta dalam pelatihan dikarenakan mereka sangat 
membutuhkan analisis statistik (angket no $3)$.

Hasil untuk angket no 5 (Apakah pelatihan ini efektif), sebanyak hampir $70 \%$ menjawab sangat efektif namun sekitar 30 persen menyatakan kurang efektif. Hal ini bisa disebabkan oleh waktu (durasi) pelatihan (angket no 6), dimana hampir 60 persen peserta menyatakan bahwa lama pelatihan adalah kurang. Sehingga sebagian besar peserta menyarankan untuk melakukan pelatihan lanjutan seperti yang telah disebutkan diatas.

\section{KESIMPULAN}

Dari uraian diatas, dapat disimpulkan bahwa analisis statistik bagi guru guru di SMA Kediri untuk karya tulis ilmiah sangatlah mereka butuhkan, namun terdapat kendala yaitu tidak adanya software statistika yang mereka butuhkan. Sehingga dengan melakukan pelatihan analisis statistika ini mampu menjadi salah satu alternatif untuk menjawab beberapa permasalahan guru guru di Kediri didalam menulis karya tulis ilmiah. Dalam pelaksanaan pelatihan tersebut juga sudah mencapai target keberhasilan dari kriteria evaluasi menggunakan soal dan juga adanya respon positif dari peserta. Sedangkan pelatihan analisis statistik lanjutan perlu ditindaklanjuti untuk memenuhi kebutuhan guru guru di SMA Kediri didalam menulis suatu karya ilmiah.

\section{UCAPAN TERIMA KASIH}

Tim PKM mengucapkan terima kasih kepada Fakultas Matematika dan Ilmu
Pengetahuan Alam yang telah mendukung pelaksanaan PKM melalui dana DIPA Unesa anggaran tahun 2018.

\section{PUSTAKA}

Schaffhauser, D., 2016, OECD : Teacher professionalism needs improvement worldwide, The Journal

Creasy, K.L., 2015, Defining Professionalism in Teacher Education Programs, Journal of Education and Social Policy, Vol 2 No 2, pp 23-25

Setyarsih W., Dwiningsih, K dan Tukiran, 2017, Penyusunan Karya Tulis Ilmiah Bagi Guru SMAN Di Kabupaten/Kota Gresik, Jurnal Abdi, Vol 3 No 1, pp 22-31.

Maclellan, 2016, Why don't teachers use education research in teaching, Education in Chemistry.

Sumardjoko, B., 2018, Teachers's Poor professionalism of writing a scientific paper at Muhammadiyah Senior High School in Central Java, Intenational Journal of Pedagogy and Teacher Education, Vol 2, no 1, pp 267-277

Widodo, E., Rosana, D dan Setyawarno, D, 2018, Pemanfaatan Buku Ajar Statistik Terapan dan Aplikasi SPP untuk Meningkatkan Kompetensi Meneliti bagi Guru IPA Tingkat SMP di Sleman, Yogjakarta, Jurnal Pengabdian Masyarakate MIPA dan Pendidikan MIPA, Vol 2 No 1, pp 33-37 